\title{
The effect of role conflict on academic burnout of undergraduate Economics students
}

\author{
Ayu Dina Kristina ${ }^{1^{*}}$, J.T. Lobby Loekmono ${ }^{2}$, Setyorini ${ }^{3}$ \\ ${ }_{1,2,3}$ Satya Wacana Christian University, Salatiga, Indonesia \\ *Corresponding author, e-mail: ayudinachristina@gmail.com
}

\begin{abstract}
Role conflict is experienced by students when incompatible demands relatively rated to a set of standards or conditions that influence their role performance. When students continuously experience role conflict, it leads to academic burnout. Therefore, this research aims to determine the significant effect of role conflict on academic burnout of undergraduate economics students. This is a quantitative research, with data obtained from a total of 114 undergraduate economics students consisting of $29 \%$ males and $71 \%$ females using the Role Questionnaire (Rizzo et al., 1970) and Maslach Burnout Inventory Student Survey (MBI-SS) (Schaufeli et al., 2002). The result of simple linear regression analysis showed that the values of $\beta$ and sig. are 0.023 and $0.343(>0.05)$, which means that the effect of role conflict on academic burnout among students is insignificant.
\end{abstract}

Keywords: Role Conflict, Academic Burnout, Economics

How to Cite: Kristina, A. D., Loekmono, J. T. L., \& Setyorini, S. (2020). The effect of role conflict on academic burnout of undergraduate Economics students. International Journal of Research in Counseling and Education, 4(2), 98-103. doi:https://doi.org/10.24036/00333za0002

\section{Introduction}

Burnout was first introduced by Freudenberger (1975), which means to fail, wear out or become exhausted due to excessive energy demands. It is measured using the Maslach Burnout Inventory developed by Christina Maslach and Jackson in 1981. Studies on the first concept of burnout were related to human services such as health, education, and social work. Besides, carrying out researches on burnout syndrome, other professional studies were conducted (Leiter \& Schaufeli, 1996).

According to Schaufeli et al. (2002), the burnout experienced by students is called "academic burnout." Lin \& Huang (2014) stated that students experience middle-high level of burnout during the learning process compared to nurses, counselors, and educators. Academic burnout is students' feeling of exhaustion due to the demands of study, cynical attitude (cynicism), and lack of interest in lectures and assignments thereby leading to reduced academic efficacy (Schaufeli et al., 2002). When students' experience academic burnout, it adversely affects their studies such as absence in the class, poor performance in carrying out tasks, reduced academic achievement, inability to complete assignments, and potentially dropping out from the university (Law, 2010). Sutarjo et al. (2013) also reported that academic burnout leads to decrease in learning motivation, laziness, and a decline in learning achievements.

Students of Satya Wacana Christian University are required to take a minimum of 144 SKS studies, work for 3 months in an off-campus institution, make final task research, and collect organizational activity points culminating in a minimum of 1000 points in order to obtain a bachelor's degree in economics (C. Maslach \& Leiter, 2016). These requirements indicate that students need to undergo numerous activities as undergraduate economists, which are likely to pose role conflicts Rizzo et al. (1970) defined role conflict as the compatibility or incompatibility requirements of a set of standards or conditions which impinge on performance. Role conflict is associated with stress because it is one of the dimensions of the role of stressor and antecedents factors of burnout (Lina, 2016).

The research carried out by Amelia Pangesti (2012) explained there is a significant effect of role conflict on academic burnout from 49 co-ass students. However, this study was different from Lina \& Hartono Kusuma 
(2018) study, which stated that the effect of the role conflict on academic burnout among students is insignificant. Data from the pre-research was conducted on February 24th, 2020, as shown in Table 1.

Table 1. Role Conflict and Academic Burnout Categories

\begin{tabular}{lcccccccccc}
\hline \multirow{2}{*}{ Study Program } & \multicolumn{2}{c}{ Very Low } & \multicolumn{2}{c}{ Low } & \multicolumn{2}{c}{ Neutral } & \multicolumn{2}{c}{ High } & \multicolumn{2}{c}{ Very High } \\
\cline { 2 - 11 } & RC & AB & RC & AB & RC & AB & RC & AB & RC & AB \\
\hline Economics Management & $0 \%$ & $3 \%$ & $46 \%$ & $40 \%$ & $37 \%$ & $46 \%$ & $17 \%$ & $11 \%$ & $0 \%$ & $0 \%$ \\
Accounting & $0 \%$ & $14 \%$ & $26 \%$ & $46 \%$ & $66 \%$ & $37 \%$ & $9 \%$ & $0 \%$ & $0 \%$ & $3 \%$ \\
Economics & $0 \%$ & $0 \%$ & $6 \%$ & $9 \%$ & $37 \%$ & $40 \%$ & $54 \%$ & $46 \%$ & $3 \%$ & $2 \%$ \\
\hline
\end{tabular}

The table comprising of 105 students shows that $54 \%$ and $46 \%$ had high role conflict and academic burnout in Economics compared to other studies. The pre-research result means there is a possible effect of role conflict on academic burnout among economics students, which is similar to the research carried out by Amelia Pangesti (2012). Therefore, this research focuses on determining the effects of role conflict on academic burnout of undergraduate economics students.

\section{Method}

This is an ex post facto research, which means that the test hypotheses do not provide specific treatment or manipulation (Azwar, 2012). Ex post facto aims to determine possible causes for changes in behavior, symptoms, or phenomena due to the occurrence of events on the independent variable. The research sample was a total of 114 undergraduate economics students consist of 2019, 2018 and 2017 academic sessions of Satya Wacana Christian University in Indonesia, which consists of $29 \%$ males and $71 \%$ females (Sugiyono, 2014). Role conflict was measured using several instruments such as Role Questionnaire (RQ) (Rizzo et al., 1970), Role Conflict and Ambiguity (RCA) Scales (Schuler et al., 1977), Role Conflict Scale (Pandey, 1999; Malhotra \& Sachdeva, 2005), and Role Conflict \& Role Ambiguity Inventory (RCRAI) (Olk \& Friedlander, 1992). Subsequently, the academic burnout was measured using several instruments such as Shirom-Melamed Burnout Measure (Melamed et al., 2006), Burnout Measure (Pines \& Aronson, 1988; Malach-Pines, 2005), Copenhagen Burnout Inventory (Kristensen et al., 2005), Oldenburg Burnout Inventory (Demerouti, 1999; Demerouti et al., 2002), Bergen Burnout Inventory (Matthiesen S., 1992) and Maslach Burnout Inventory (Maslach \& Jackson, Leiter, 1996; Guzzi, 2019)

Subsequently, the role conflict was measured using Role Questionnaire (RQ) (Rizzo et al., 1970) consist of 15 items, and the academic burnout used Maslach Burnout Inventory Student Survey (MBI-SS) (Schaufeli et al., 2002) consist of the same number of items. RQ consists of four subscales, namely Intrasender, Intersender, Interrole and Intrarole conflicts, which were measured with five, four, two and four items, respectively. The original alternative answers of Role Conflict which was seven-point and ranged from 1 "Very False" to 7 "Very True" were changed to four-point because it tends to obscure the differences that need to be measured (Azwar, 2013). Meanwhile, MBI-ss consists of three subscales, namely Exhaustion, Cynicism, and Reduced Academic Efficacy, which was measured with five, four and six items, respectively. The answers choice, which had sevenpoint ranging from 0 "Never" to 6 "Always" were changed to four.

These instruments used back translation technique with expert judgment shared online using Google Form. Both instruments were tested for validity $(\mathrm{RQ}=0.280-0.829$; MBI-SS $=0.414-0.750)$ (Ali, 1987) and reliability $(R Q=0.912 ; \mathrm{MBI}-\mathrm{SS}=0.889)(\mathrm{D} . \&$ P., 2003). Data analysis was carried out using the descriptive and simple linear regression analysis with SPSS version 26.0 for Windows. This is because the simple linear regression analysis was to predict the extent a dependent variable's value changes assuming the value of one independent move up or down (Sugiyono, 2014).

\section{Results and Discussion}

Information of role conflict and academic burnout level by 114 economics students. Figure 1 shows that most of the economics students were a neutral level of role conflict (53\%) and academic burnout (62\%). It means that there was a difference in categorization results between pre-research and real-research, which caused limited samples and differences in the implementation of data retrieval. The table bellow shows the result of regression for role conflict on academic burnout 


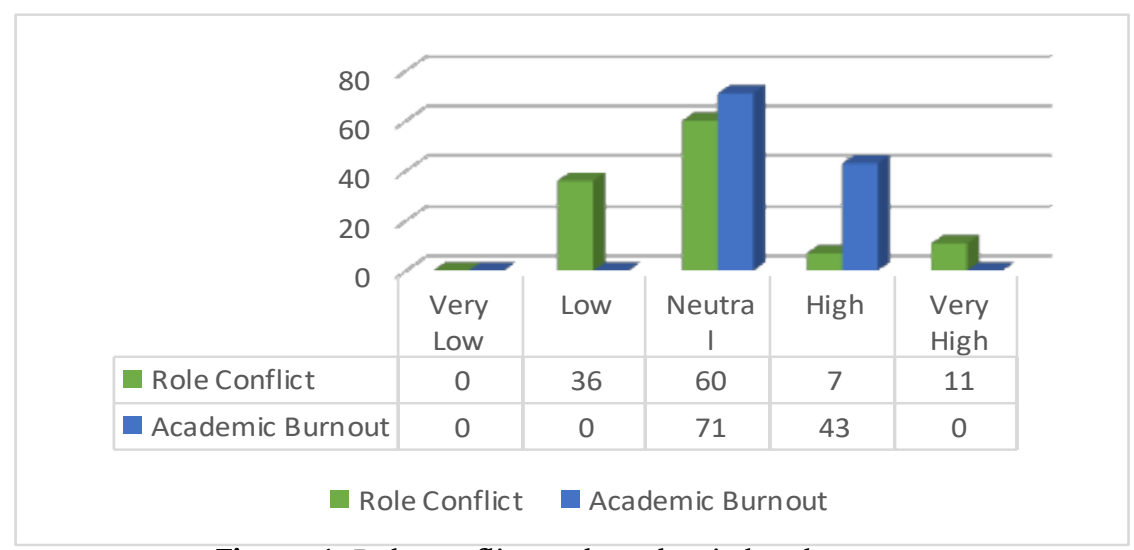

Figure 1. Role conflict and academic level

Table 1 shows that only $0.8 \%$ of academic burnout in students was due to role conflict, while other factors influence 99.98\%. Furthermore, tables 2 and 3 show that a significant score of $0.343>0.05$ and $\beta=0.023$ means that the effect of role conflict on academic burnout is insignificant.

Table 2. Model Summary of role conflict on academic burnout

\begin{tabular}{lcccc}
\hline \multicolumn{4}{c}{ Model Summary } \\
\hline Model & $\mathrm{R}$ & $\mathrm{R}$ Square & $\begin{array}{c}\text { Adjusted } \mathrm{R} \\
\text { Square }\end{array}$ & $\begin{array}{c}\text { Std. Error of the } \\
\text { Estimate }\end{array}$ \\
\hline 1 & $.090^{\mathrm{a}}$ & .008 & -.001 & 2.00471 \\
\hline
\end{tabular}

Table 3. Anova of role conflict on academic burnout

\begin{tabular}{lrrrrr}
\hline Model & Sum of Squares & df & Mean Square & F & \multicolumn{1}{c}{ Sig. } \\
\hline Regression & 3.642 & 1 & 3.642 & & \\
Residual & 450.112 & 112 & 4.019 & .906 & $.343^{\mathrm{b}}$ \\
Total & 453.754 & 113 & & & \\
\hline
\end{tabular}

Table 4. Coefficients of role conflict on academic burnout

\begin{tabular}{|c|c|c|c|c|c|c|}
\hline \multirow{2}{*}{ Model } & & \multicolumn{2}{|c|}{$\begin{array}{l}\text { Unstandardized } \\
\text { Coefficients }\end{array}$} & \multirow{2}{*}{$\begin{array}{c}\text { Standardized } \\
\text { Coefficients } \\
\text { Beta }\end{array}$} & \multirow[t]{2}{*}{$\mathrm{t}$} & \multirow[t]{2}{*}{ Sig. } \\
\hline & & $\mathrm{B}$ & Std. Error & & & \\
\hline 1 & $(0$ & 25.021 & .901 & & 27.763 & .000 \\
\hline & Role_Conflict_X & .023 & .024 & .090 & .952 & .343 \\
\hline
\end{tabular}

According to Cohen et al. (2007), the larger the samples from the existing population, the better the role conflict. The pre-research in this study was less than the number of samples from the real research because it was conducted after the Covid-19 pandemic. This is because of the Circular Letter of the Ministry of Education No. 36962/MPK.A/HK/2020 on "Learning Online and Working from Home to prevent Covid-19 Spread" demanded all educational institutions to conduct online learning (Kemendikbud RI, 2020). It tends to have an impact on students because assignments were given more by lecturers online than at face-to-face. Caputo (1991) reported that the causes of academic burnout are role conflict and public interaction. When students feel they do not match the role assigned by the lecturer, role conflict occurs. Similarly, when lectures give group 
assignments to students, it tends to bring up role conflict due to differences in goals, philosophies, and expectations.

Furthermore, there is a direct public interaction that requires students to interact socially with their group of friends to complete tasks, which can be exhausting. Role conflict does not affect academic burnout due to the absence of direct social interaction during online learning in Covid-19. This is because students only interact through technology-based learning media or applications. It means despite the role conflict in students, the tendency to feel emotional fatigue reduced, therefore eliminating academic burnout.

This study shows that many other factors influence the role of conflict. For instance, Maslach \& Leiter (2016) stated that there are factors that influence the emergence of academic burnout such as workload, control, reward, community, fairness, and values. These factors can trigger the onset of academic burnout because unmarried individuals are at risk of higher burnout (Swasti et al., 2018). Law (2010) reported that academic burnout negatively affects studies, such as absence from college, not carrying out lecture stints properly, declining academic achievement, not completing undergraduate studies and potential drop out from college (Law, 2010).

This finding was in line with the study carried out by Lina \& Hartono Kusuma (2018). According to them, there the effect of role conflict on academic burnout to 107 students was insignificant due to the use of subjects with sufficient samples in the same scope as majoring in economics, such as those studying without practice/internship. Figure 1 shows that students' role conflict on a neutral level meaning predisposed did not accept many of the role demands in order not to create a role conflict. In addition, Lina \& Hartono Kusuma (2018) stated that women were the most favored gender by 71\%. Kristiyana (2018) stated that there is no difference in the role conflict in men or a woman, which is also in line with the research carried out by Gusnita et al. (2014) and Tinggi et al. (2011) on academic burnout.

Conversely, the research carried out by Amelia Pangesti (2012), reported that there is a significant effect of role conflict on academic burnout among students. This finding was in accordance with the research conducted by Ayu et al. (2017), Dasgupta (2012) and Wiryathi (2014). Differences in result study are caused by several things, including (1) different sampling techniques. For instance, Amelia Pangesti (2012) used the purposive sampling techniques with 49 students that were conducting practice or internship as doctors for approximately 6 months in Indonesian Christian University Hospital. This means that these students played two roles as students and doctors serving patients. These two heavy roles tend to be role conflict that leads to academic burnout due to the imbalance between the demands in the job and the security of individuals in resolving conflict.

Similarly, Schaufeli et al. (2009) stated that stress often occurs to individuals when more time is spent in a particular role, and others are neglected. When stress occurs, it triggers the appearance of mental fatigue, physical and emotional burnout (Lyon et al., 2012). However, this research which was carried out using the economics subject students that undergo lecture studies was similar to the (2) research carried out by Amelia Pangesti (2012) using Maslach Burnout Inventory General Survey (MBI-GS) (C. Maslach et al., 1996) with the addition of 22 items (original instruments), thereby culminating in 26 items. Meanwhile, this research used the development of MBI-GS aimed at students, namely the MBI Students Survey (Schaufeli et al., 2009) consisting of 15 items.

\section{Conclusion}

In conclusion, the effect of role conflict on academic burnout of economics students is insignificant. This means that an increase in students' academic burnout is not determined by role conflict. Furthermore, there are many factors related to its effect on academic burnout such as workload, control, reward, community, fairness, values. Therefore, students' academic burnout needs to negatively affect their academic performance, such as being absent in the class, not carrying out tasks properly, reducing academic achievement, not completing undergraduate studies even, potentially dropping out from university. Subsequently, further research needs to be conducted using additional variables such as workload, control, reward, community, fairness, values with multiple analysis regression.

\section{References}

Ali, M. (1987). Penelitian Kependidikan Prosedur \& Strategi. Bandung: Angkasa.

Amelia Pangesti, A. (2012). Pengaruh Konflik Peran Terhadap Terjadinya Burnout Pada Mahasiswa Koass. JPPP - Jurnal Penelitian Dan Pengukuran Psikologi, 1(1), 1. https://doi.org/10.21009/jppp.011.01

Ayu, I. G., Budiasih, N., Akuntansi, P. S., Ekonomi, F., \& Udayana, U. (2017). Burnout Pada Auditor Di Kantor 
Akuntan Publik Provinsi Bali. Burnout Pada Auditor Di Kantor Akuntan Publik Provinsi Bali, 5(3), 15891600. https://doi.org/10.17509/jrak.v5i3.9222

Azwar, S. (2012). Penyusunan Skala Psikologi (2nd ed.). Yogyakarta: Pustaka Pelajar.

Azwar, S. (2013). Metode Penelitian. Yogyakarta: Pustaka Pelajar.

Caputo. (1991). Stress and Burnout in Library Service. Canada: Oryx Press.

Cohen, L., Manion, L., \& Morrison, K. (2007). Research Methods in Education (6th ed.). NY:Routledge Falmer.

D., G., \& P., M. (2003). Using SPSS for Windows Step by Step: A Simple Guide and Reference(4th ed.). London: Pearson Education.

Dasgupta, P. (2012). Effect of Role Ambiguity, Conflict and Overload in Private Hospitals' Nurses' Burnout and Mediation Through Self Efficacy. Journal of Health Management, 14(4), 513-534. https://doi.org/10.1177/0972063412468980

Demerouti, E., Bakker, A., Nachreiner, F., \& Ebbinghaus, M. (2002). From mental strain to burnout. European Journal of Work and Organizational Psychology, 11(4), 423-441. https://doi.org/10.1080/13594320244000274

Freudenberger, H. J. (1975). The staff burn out syndrome in alternative institutions. Psychotherapy, 12(1), $73-$ 82. https://doi.org/10.1037/h0086411

Gusnita, R., Herawati, \& Rifa, D. (2014). Pengaruh Stressor dan Tipe Kepribadian Terhadap Kejenuhan (Burnout) pada Kantor Akuntan Publik di Padang dan Pekan Baru. Jurnal Akuntansi Bung Hatta, 4(1), 1-11.

Guzzi, D. (2019). Redefining Burnout: Exploring Common Conceptualizations and the Neurophysiology of Chronic Stress to Establish an Integrated Allostatic Model. https://digitalcommons.nl.edu/diss/374/

Kemendikbud RI. (2020). Pembelajaran Secara Daring dan Bekerja dari Rumah dalam Rangka Pencegahan Penyebaran Corona Virus Disiase (COVID-19). https://www.jogloabang.com/sites/default/files/dokumen/Pembelajaran secara Daring dan Bekerja dari Rumah.pdf diakses pada 22 Agustus 2020

Kristensen, T. S., Borritz, M., Villadsen, E., \& Christensen, K. B. (2005). The Copenhagen Burnout Inventory: A new tool for the assessment of burnout. Work and Stress, 19(3), 192-207. https://doi.org/10.1080/02678370500297720

Kristiyana, N. (2018). Perbedaan Gender dalam Peran Konflik, Emosional Kerja, dan Kinerja Pegawai Marketing Perusahaan Farmasi di Jawa Tengah. Jurnal Maksipreneur: Manajemen, Koperasi, Dan Entrepreneurship, $8(1), 45$. https://doi.org/10.30588/jmp.v8i1.378

Law, D. W. (2010). A Measure of Burnout for Business Students. Journal of Education for Business, 85(4), 195202. https://doi.org/10.1080/08832320903218133

Leiter, M. P., \& Schaufeli, W. B. (1996). Anxiety, Stress \& Coping : An Consistency of the burnout construct across occupations CONSISTENCY OF THE BURNOUT CONSTRUCT. December 2012, 37-41.

Lin, S. H., \& Huang, Y. C. (2014). Life stress and academic burnout. Active Learning in Higher Education, 15(1), 77-90. https://doi.org/10.1177/1469787413514651

Lina. (2016). Development of Role Stressors Model towards Burnout: Empirical Study from Indonesia. Proceedings of the International Conference on Accounting Studies (Icas) 2016, August, 319+.

Lina, -, \& Hartono Kusuma, B. (2018). Pengaruh Role Stressor Terhadap Burnout dan Perbedaan Burnout Berdasarkan Gender: Studi Empiris pada Mahasiswa. Jurnal Akuntansi Maranatha, 101), 62-71. https://doi.org/10.28932/jam.v10i1.929

Lyon, I. A. E., France, U. L., Roger, A., \& Asadullah, M. A. (2012). IMPACT OF ORGANIZATIONAL ROLE STRESSORS ON FACULTY STRESS \& BURNOUT: (An exploratory analysis of a public sector university of Pakistan). 4ème Colloque International ( ISEOR - AOM ), 1-18. http://halshs.archivesouvertes.fr/docs/00/69/88/06/PDF/STRESS_BURNOUT-ISEOR_AOM.pdf

Malach-Pines, A. (2005). The burnout measure, short version. International Journal of Stress Management, 12(1), 78-88. https://doi.org/10.1037/1072-5245.12.1.78

Malhotra, S., \& Sachdeva, S. (2005). Social roles and role conflict: An interprofessional study among women. Journal of the Indian Academy of Applied ..., 31(1-2), 37-42. http://medind.nic.in/jak/t05/i1/jakt05i1p37.pdf 
Maslach, C., \& Leiter, M. P. (2016). Burnout. Stress: Concepts, Cognition, Emotion, and Behavior: Handbook of Stress, 351-357. https://doi.org/10.1016/B978-0-12-800951-2.00044-3

Maslach, C., S.E., J., \& M.P., L. (1996). Maslach Burnout Inventory(3rd ed.). Consulting Psychologist Press.

Maslach, Christina, \& Jackson, S. E. (1981). The measurement of experienced burnout. Journal of Organizational Behavior, 2(2), 99-113. https://doi.org/10.1002/job.4030020205

Matthiesen S. (1992). The Bergen Burnout Indicator. Bergen: University of Bergen Press.

Melamed, S., Shirom, A., Toker, S., Berliner, S., \& Shapira, I. (2006). Burnout and risk of cardiovascular disease: Evidence, possible causal paths, and promising research directions. Psychological Bulletin, 132(3), 327353. https://doi.org/10.1037/0033-2909.132.3.327

Murtiasri, E. (2006). Anteseden Dan Konsekuensi Burnout Pada Auditor: Pengembangan Terhadap Role Stress Model. In Maksi (Vol. 7).

Olk, M. E., \& Friedlander, M. L. (1992). Trainees’ Experiences of Role Conflict and Role Ambiguity in Supervisory Relationships. Journal of Counseling Psychology, 39(3), 389-397. https://doi.org/10.1037/00220167.39.3.389

Rizzo, J. R., House, R. J., \& Lirtzman, S. I. (1970). Role Conflict and Ambiguity in Complex Organizations. Administrative Science Quarterly, 15(2), 150. https://doi.org/10.2307/2391486

Schaufeli, W. B., Leiter, M. P., \& Maslach, C. (2009). Burnout: 35 years of research and practice. Career Development International, 14(3), 204-220. https://doi.org/10.1108/13620430910966406

Schaufeli, W. B., Martínez, I. M., Pinto, A. M., Salanova, M., \& Barker, A. B. (2002). Burnout and engagement in university students a cross-national study. Journal of Cross-Cultural Psychology, 33(5), 464481. https://doi.org/10.1177/0022022102033005003

Schuler, R. S., Aldag, R. J., \& Brief, A. P. (1977). Role conflict and ambiguity: A scale analysis. Organizational Behavior and Human Performance, 201), 111-128. https://doi.org/10.1016/0030-5073(77)90047-2

Sugiyono. (2014). Statistik untuk Penelitian. Bandung: Alfabeta.

Sutarjo, I., Putri, S., \& Suarni, M. (2013). Efektivitas Teori Behavioral Teknik Relaksasi Dan Brain Gym Untuk Menurunkan Burnout Belajar Pada Siswa Kelas Viii Smp Laboratorium Undiksha Singaraja Tahun Pelajaran 2013/2014. Jurnal Jurusan Bimbingan Dan Konseling Undiksha, 2(1).

Swasti, K. G., Ekowati, W., \& Rahmawati, E. (2018). Faktor-Faktor yang Mempengaruhi Burnout pada Wanita Bekerja di Kabupaten Banyumas. Jurnal Keperawatan Soedirman, 12(3), 190. https://doi.org/10.20884/1.jks.2017.12.3.738

Tinggi, S., Ekonomi, I., Rutu, S., Ambon, N., \& No, J. K. (2011). Konsekuensi Konflik Peran , Kelebihan Beban Kerja dan Motivasi Intrinsik terhadap Burnout pada Dosen yang. 13(2), 111-122.

Wiryathi, R. (2014). Volume.03.no.05 tahun 2014. E-Jurnal Ekonomi Dan Bisnis Universitas Udayana 3.5 (2014): 227-244, 05. 